\title{
Electrolytes and Nutritional Element Assessment among Iraqi Cancer Patients Receiving Chemotherapy
}

\author{
Mohammed Salim Abdulrahman ${ }^{1 *}$, Hedef D. El-Yassin ${ }^{1}$, Nada A. S. Alwan² \\ ${ }^{1}$ Department of Clinical Biochemistry, College of Medicine, University of Baghdad, Iraq; ${ }^{2}$ National Cancer Research Center, \\ University of Baghdad, Iraq
}

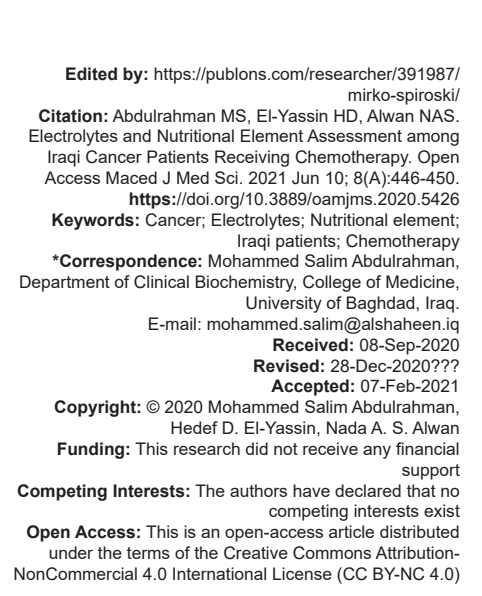

Introduction

Cancers are a broad entity of complex diseases with an irregular pattern of cell growth that can invade or metastasize other areas of the organism. It is the world's leading cause of mortality with 9.6 million deaths reported in 2018 . The most common causes of cancer related death are due to lung, breasts, stomach, and colonic cancers [1].

Acid-base and electrolyte disorders (AEDs) could affect human body disequilibrium involving malnutrition processes and endocrine dysfunction. The electrolyte disturbances could be mediated by the tumor pathology itself or by the treatment [2]. In the United States, the direct costs of treating the associated hyponatremia exceeded $\$ 1.6$ billion per year [3].

Early detection and prompt correction of AEDs can improve patients' short-term outcome and quality of life [4]. However, the epidemiology of AEDs in cancer patients and its relationship with clinical outcomes requires further studies.

We aimed to assess the electrolyte and protein changes in cancer patients on chemotherapy.
A cohort study was carried out on 100 newly diagnosed patients with cancer before undergoing chemotherapy treatment in Al-Amal National Radiation Oncology Hospital in Baghdad, Iraq, during the period from January 2019 to July 2019. The study protocol was approved by the institutional review board in accordance with the principles of the Declaration of Helsinki. Assessments of the studied samples were conducted as a baseline measure before receiving chemotherapy or radiotherapy (designated as TO) and in the period after the third cycle of chemotherapy (termed as Tx).

\section{Patients criteria for inclusion}

The following criteria were included in the study:

(1) All newly diagnosed patients with cancer aged $\geq 18$ years; (2) patients who did not yet start the first cycle of chemotherapy regimen; and (3) those who are in a competent mental and physical status and willing to participate in the study team. 


\section{Patient criteria for exclusion}

The following criteria were excluded from the study:

(1) Patients who are already started the chemotherapy regiment; (2) patients who are unable to answer the questionnaires (due to physical or mental impairment); and (3) deteriorated performance status participants.

\section{Quantitative dietary assessment}

Anthropometric measurement included weight, height, and body mass index (BMI). Quantitative dietary assessment was made for: Magnesium, calcium, sodium, chloride, potassium, zinc, $\mathrm{Hb} 1 \mathrm{Ac}$, total protein and ferritin.

A hundred patients with Iraqi carcinoma of various types, grades, and stages have been sequentially evaluated before chemotherapy and radiotherapy, regardless of their chemical purposes (curative, neoadjuvant, adjuvant, or palliative). They were selected in the waiting room for a medical test at the cancer center in this hospital. The patients approval was confirmed by signing written formal consent. The follow-up time depending on the chemotherapy treatment was about 2-3 months. The chemical parameters were measured using ELISA technique.

Statistically, patients data were analyzed using SPSS software version 25. Descriptive statistics tabulated as mean, standard deviation, range, frequencies, and proportions. Paired Student's t-test for variables levels was done. Level of significance of $\leq 0.05$ was considered as significant difference or correlation.

\section{Results}

Patients demographics and characteristics are summarized in Table 1. Table 1: Demographic distribution and characteristics of the study population $(n=100)$

\begin{tabular}{lll}
\hline Variables & & No (\%) \\
\hline Gender & Male & $23(23)$ \\
& Female & $77(77)$ \\
Age & $<20$ & $1(1)$ \\
& $20-40$ & $21(21)$ \\
& $41-60$ & $55(55)$ \\
Occupation & $>60$ & $23(23)$ \\
& Working & $21(21)$ \\
Comorbidity & Not working & $77(77)$ \\
& Student & $2(2)$ \\
BMI & Present & $38(38)$ \\
& Not Present & $62(62)$ \\
& Under-weight & $5(5)$ \\
Type of & Normal & $20(20)$ \\
cancer & Over-weight & $30(30)$ \\
& Obese & $45(45)$ \\
& Breast & $55(55)$ \\
& & \\
& Colorectal & $14(14)$ \\
& Lung & $11(11)$ \\
& Ovary & $5(5)$ \\
& Bladder & $5(5)$ \\
& Stomach & $2(2)$ \\
& Lymphoma & $2(2)$ \\
& NPC & $1(1)$ \\
& Larynx & $1(1)$ \\
& Pancreas & $1(1)$ \\
& Prostate & $1(1)$ \\
RCC & $1(1)$ \\
Cervix & $1(1)$ \\
\hline
\end{tabular}

In general, females constituted $77 \%$ of the cohort. The mean age was $50.15 \pm 13.08$ years with a median of 50 years. Obesity was reported in $45 \%$ of the cohort. The top three malignancy in the cohort were breast cancer 55 (55\%), 14\% colorectal and $11 \%$ lung.

Eight different chemotherapeutic protocols were prescribed to patients according the primary malignancy included Adriamycin, cyclophosphamide and Taxen for $54 \%$ of the cohort, Carboplatin and Taxen for $16 \%$, Xelox for $14 \%$, Gemcitabine for $5 \%$, Taxen for $5 \%, 5 \mathrm{FU}$ and Cisplatin for $3 \%$, ABVD for $2 \%$ and FOLFIRINOX for $1 \%$.

As Table 2 shows, there has been significant reduction in the level of magnesium and zinc after chemotherapy course ( $P$ - value $<0.0001)$. Subtle reduction was seen in the other electrolytes which were statically not significant.

\begin{tabular}{llll}
$\begin{array}{l}\text { Table 2: } \\
\text { post-chemotherapy }\end{array}$ & $\begin{array}{l}\text { Concentration } \\
\text { of }\end{array}$ & electrolytes & pre-and \\
\hline $\begin{array}{l}\text { Parameter } \\
\text { (normal value) }\end{array}$ & Pre-chemotherapy & Post-chemotherapy & $\begin{array}{l}\text { Paired t-test } \\
\text { P-value }\end{array}$ \\
\hline $\begin{array}{l}\text { Magnesium } \\
(1.5-2.3 \mathrm{mg} / \mathrm{dL})\end{array}$ & $2.22 \pm 0.34 \mathrm{mg} / \mathrm{dL}$ & $1.88 \pm 0.36 \mathrm{mg} / \mathrm{dL}$ & $<0.0001^{*}$ \\
$\begin{array}{l}\text { Calcium } \\
(8.7-10.2 \mathrm{mg} / \mathrm{dL})\end{array}$ & $9.55 \pm 0.63 \mathrm{mg} / \mathrm{dL}$ & $9.40 \pm 0.61 \mathrm{mg} / \mathrm{dL}$ & 0.0798 \\
$\begin{array}{l}\text { Sodium } \\
(136-146 \mathrm{mmol} / \mathrm{L})\end{array}$ & $136.98 \pm 4.58 \mathrm{mmol} / \mathrm{L}$ & $136.01 \pm 4.75 \mathrm{mmol} / \mathrm{L}$ & 0.1435 \\
$\begin{array}{l}\text { Chloride } \\
(102-109 \mathrm{mmol} / \mathrm{L})\end{array}$ & $103.17 \pm 2.54 \mathrm{mmol} / \mathrm{L}$ & $103.85 \pm 2.64 \mathrm{mmol} / \mathrm{L}$ & 0.0848 \\
$\begin{array}{l}\text { Potassium } \\
(3.5-5 \mathrm{mmol} / \mathrm{L})\end{array}$ & $4.64 \pm 0.61 \mathrm{mmol} / \mathrm{L}$ & $4.66 \pm 0.57 \mathrm{mmol} / \mathrm{L}$ & 0.8118 \\
$\begin{array}{l}\text { Zinc } \\
(75-120 \mu \mathrm{\mu g} / \mathrm{dL})\end{array}$ & $89.42 \pm 13.37 \mu \mathrm{g} / \mathrm{dL}$ & $78.51 \pm 13.56 \mu \mathrm{g} / \mathrm{dL}$ & $<0.0001^{*}$
\end{tabular}

Significant reduction in total protein level was seen post chemotherapy ( $P$-value $=<0.0001$, Figure 1$)$. There was also a marginal yet significant increase in the level of HbA1c post chemotherapy $(P-$ value $=0.0434$, Figure 2).

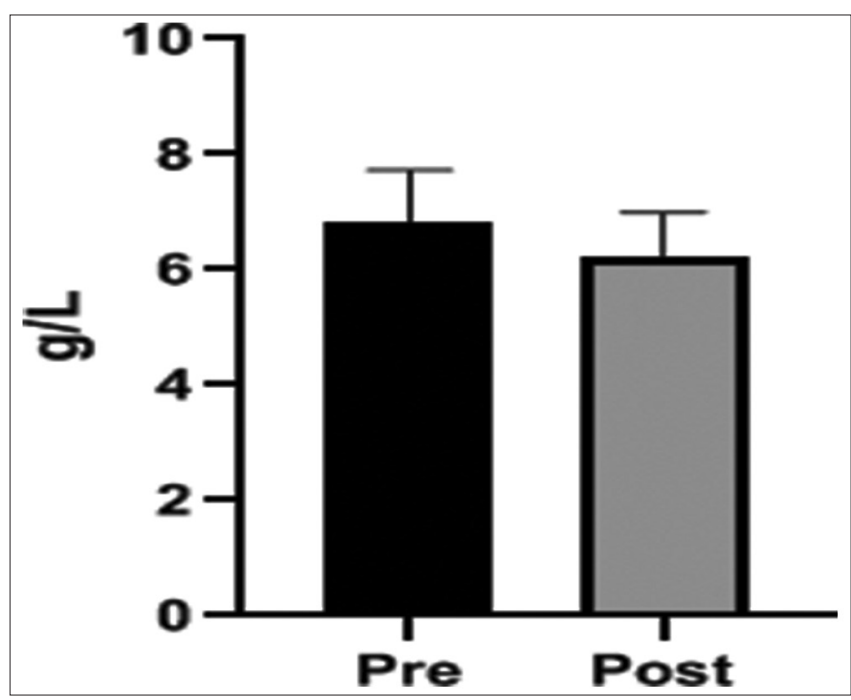

Figure 1: Total proteins concentration pre- and post-chemotherapy in terms of mean $\pm S D$

Ferritin levels showed elevation in both males and females, however, the changes were statistically significant only in females $(P$ - value $=0.0327$ vs $P$ value $=0.3074$, Figure 3 ) . 


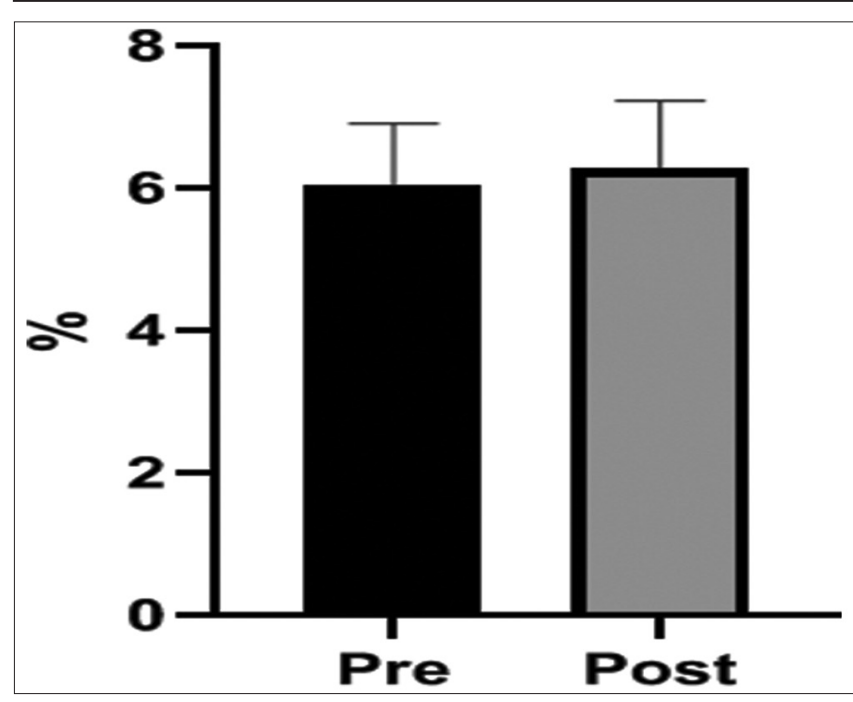

Figure 2: HbA1c concentration pre- and post-chemotherapy in terms of mean $\pm S D$

\section{Discussion}

In our study, the recruited cancer patients comprised patients with various types, grades, and stages of cancer treated with different modalities.

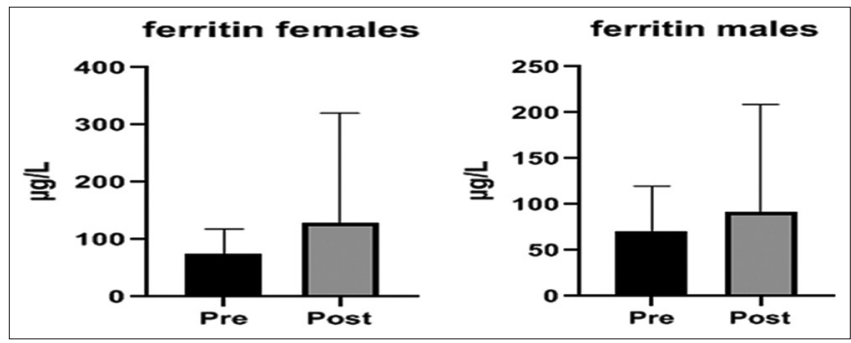

Figure 3: Ferritin concentration pre- and post-chemotherapy in terms of mean $\pm S D$ for females and males, respectively

The mean \pm SD of the BMl of the patients was $30.62 \pm 5.51 \mathrm{~m}^{2} / \mathrm{Kg}$ with a median of $30.05 \mathrm{~m}^{2} / \mathrm{Kg}$. Overweight and moderate obesity were noted among $30 \%$ and $28 \%$, respectively. On the other hand, severe obesity, underweight, and morbid obesity were displayed in $16.3 \%, 5 \%$, and $1 \%$ of patients, respectively.

Magnesium levels showed a decrease with high statistical significance; similar findings were reported in another study [5]. This could be attributed to the effect of cytotoxic drugs (cisplatin) which impairs the renal tubular absorption of magnesium [6]. Similarly, a decline in the calcium rates was observed, though not significant, which could be secondary to hypomagnesemia [7], hypoalbuminemia [8], tumor lysis [9], [10], or hyperphosphatemia [11].

Hyponatremia may be attributed to cancer itself or treatment in cancer patients. Vincristine, ifosfamide, melphalane, and cyclophosphamide are reported to induce hyponatremia in chemotherapeutics through disrupting other hormones as cortisol. Nausea and pain typically recorded in patients with cancer can often promote the development of antidiuretic hormones and contribute to hyponatremia [12]. Serum chloride levels increased post-chemotherapy, with no statistical significance. Similar results were reported by other studies which have shown no significant change of serum chloride [13]. Chloride change follows sodium change as both are extracellular ions and should keep the balance of charges of extracellular environment neutral. There was a rise in this study with no statistical significance. Some studies have reported that platinum drug chemotherapy, for example, cisplatin, may mediate hypokalemia [14]. Ifosfamide induces potassium in renal wasting, either as a proximal isolated tubular disease or as Fanconi syndrome [15]. Extrarenal hypokalemia could be attributed to reduced appetites, diarrhea, and vomiting.

Astatistical decrease was noted as well in serum levels of zinc that was consistent with numerous earlier studies [16]. Nutrients with strong anti-inflammatory properties such as Vitamin B6, magnesium, riboflavin, thiamine, zinc, and niacin have the ability to boost their anti-inflammatory cytokine profile and thus reduce the chances that certain patients have adverse health consequences [17]. Lower zinc levels may be also due to the decline of consumption. Cancer patients will excrete in their urine as much as 3 times more zinc than average persons [18]. Increased urinary zinc excretion may be associated with immune activation, renal tubular cell malfunction, and skeletal muscle catabolism in patients with cancer [19].

Protein levels in the studied patients revealed a significant decline following chemotherapy. The latter interfere with food intake and may exacerbate protein loss through urine due to inflammatory component [20]. Some studies have found a significant association between hypoalbuminemia and poor response to chemotherapy [21].

On the other hand, a statistical increase in serum levels of $\mathrm{HbA} 1 \mathrm{c}$ after chemotherapy was observed using paired Student's t-test. Such results may be due to loss of lean body weight and sarcopenic obesity development. The most plausible cause appears to be a mix of tiredness, physical inactivity, altered appetite, and sarcopenic obesity that have a detrimental impact on insulin and glucose metabolism [22]. Glycemic control and the level of $\mathrm{HbA} 1 \mathrm{c}$ are predictors for chemotherapy stoppage due to exacerbation of side effects or mediating a secondary infection. Likewise, a statistical increase in levels of serum ferritin was encountered among females. This could be due to release of ferritin from damaged liver cells as a consequence of chemotherapy [23]. Erythropoiesis suppression arising from cytotoxic treatment is likely to be at least partly responsible for this rise in serum iron [24]. Indeed, the situation is similar to that described with aplastic anemia induced by chloramphenicol, where a sudden increase in serum iron is a frontal sign of a bone marrow injury [25]. This is why the levels of ferritin are not associated with storage iron in such situations, a 
finding which is particularly relevant for cancer patients [26]. In another research, serum ferritin as a reliable therapeutic biochemical marker has been implemented to assess survival for advanced hepatobiliary cancer patients [27]. Being a mediator of inflammation, interleukin-6 is known to increase in cases of cancer, especially post-chemotherapy through inducing iron regulatory hormone (hepcidin) [28].

\section{Conclusion}

Cancer patients on chemotherapy regimens suffer from major changes in the levels of vitamins, elements, and neurotransmitter levels that affect their lifestyle, treatment course, survival, and prognosis. Frequent regular monitoring for such changes is required to harvest a positive impact on the lifestyle of patients and the treatment outcome. Chemotherapeutic regimens need to be updated in terms of quality and quantity according to the peculiar status of the patient in terms of nutritional status and neurotransmitters changes.

\section{References}

1. World Health Organization. Global Health Observatory. Geneva: World Health Organization; 2018. Available from: https://www. who.int/gho/database/en. [Last accesssed on 2018 Jun 21].

2. Rosner MH, Capasso G, Perazella MA. Acute kidney injury and electrolyte disorders in the critically ill patient with cancer. Curr Opin Crit Care. 2017;23(6):475-83. https://doi.org/10.1097/ mcc. 0000000000000450

PMid:28953555

3. Boscoe A, Paramore C, Verbalis JG. Cost of illness of hyponatremia in the United States. Cost Eff Resour Alloc. 2006;4(1):10. https://doi.org/10.1186/1478-7547-4-10 PMid: 16737547

4. Yang Y, Sun N, Sun P, Zhang L. Clinical characteristics and prognosis of elderly small cell lung cancer patients complicated with hyponatremia: A retrospective analysis. Anticancer Res. 2017;37(8):4681-6. https://doi.org/10.21873/anticanres.11872 PMid:28739771

5. Mohammed DS, Daoud FA. Assessment of dietary intake in patients with breast cancer receiving chemotherapy. Int J Sci Res. 2015;4(11):1520-5.

6. Merza W, Majid A, Daoud M, Almothaffar A. Serum magnesium concentration in patients with leukemia and lymphoma. J Fac Med Baghdad. 2008;52:101-4.

7. Karasawa T, Steyger PS. An integrated view of cisplatin-induced nephrotoxicity and ototoxicity. Toxicol Lett. 2015;237(3):219-27. https://doi.org/10.1016/j.toxlet.2015.06.012 PMid:26101797

8. Carroll B, Fleisher M, Pessin MS, Richardson S, Ramanathan LV. Pseudohypocalcemia in cancer patients: A recommendation for the postanalytical correction of serum calcium in patients with hypoalbuminemia. Clin Chem. 2017;63(7):1302-4. https://doi. org/10.1373/clinchem.2017.272997

PMid:28515104

9. Abu-Alfa AK, Younes A. Tumor lysis syndrome and acute kidney injury: Evaluation, prevention, and management. Am J Kidney Dis. 2010;55 Suppl 5:S1-3; quiz S14-9. https://doi.org/10.1053/j. ajkd.2009.10.056

PMid:20420966

10. Joshita S, Yoshizawa K, Sano K, Kobayashi S, Sekiguchi T, Morita S, et al. A patient with advanced hepatocellular carcinoma treated with sorafenib tosylate showed massive tumor lysis with avoidance of tumor lysis syndrome. Intern Med. 2010;49(11):9914. https://doi.org/10.2169/internalmedicine.49.3153 PMid:20519814

11. Askar AM. Hyperphosphatemia. The hidden killer in chronic kidney disease. Saudi Med J. 2015;36(1):13-9. https://doi. org/10.15537/smj.2015.1.9843 PMid:25629999

12. Castillo JJ, Vincent M, Justice E. Diagnosis and management of hyponatremia in cancer patients. Oncologist. 2012;17(6):756-65. PMid:22618570

13. Siddiqui A, Kumari R, Zia M, Zubair T, Imtiaz S, Sahar N, et al Correlation of duration of chemotherapy with electrolytes in cancer patients: A prospective study assessing the relationship with various electrolytes. Symbiosis. 2018;5:1-4.

14. Solomon $\mathrm{R}$. The relationship between disorders of $\mathrm{K}+$ and $\mathrm{Mg}+$ homeostasis. Semin Nephrol. 1987;7(3):253-62.

PMid:3317639

15. Da-Costa-Rocha I, Bonnlaender B, Sievers H, Pischel I, Heinrich M. Hibiscus sabdariffa L. -A phytochemical and pharmacological review. Food Chem. 2014;165:424-43. https:// doi.org/10.1016/j.foodchem.2014.05.002 PMid:25038696

16. Wang Y, Sun Z, Li A, Zhang Y. Association between serum zinc levels and lung cancer: A meta-analysis of observational studies. World J Surg Oncol. 2019;17(1):78. https://doi.org/10.1186/ s12957-019-1617-5

PMid:31060563

17. Shivappa N, Steck SE, Hurley TG, Hussey JR, Hébert JR. Designing and developing a literature-derived, population-based dietary inflammatory index. Public Health Nutr. 2013;17(8):168996. https://doi.org/10.1017/s1368980013002115 PMid:23941862

18. Schwartz MK. Role of trace elements in cancer. Cancer Res. 1975;35(11):3481-7.

PMid:1104155

19. Melichar B, Malir F, Jandik P, Malirova E, Vavrova J, Mergancova $\mathrm{J}$, et al. Increased urinary zinc excretion in cancer patients is linked to immune activation and renal tubular cell dysfunction. Biometals. 1995;8(3):205-8. https://doi. org/10.1007/bf00143377

PMid:7647517

20. Soeters PB, Wolfe RR, Shenkin A. Hypoalbuminemia: Pathogenesis and clinical significance. JPEN J Parenter Enteral Nutr. 2019;43(2):181-93. https://doi.org/10.1002/jpen.1451 PMid:30288759

21. Yokota T, Ando N, Igaki H, Shinoda M, Kato K, Mizusawa J, et al. Prognostic factors in patients receiving neoadjuvant 5-fluorouracil plus cisplatin for advanced esophageal cancer (JCOG9907). Oncology. 2015;89(3):143-51. https://doi. org/10.1159/000381065

PMid:25895447

22. Hershey DS, Hession S. Chemotherapy and glycemic control in patients with Type 2 diabetes and cancer: A comparative case 
analysis. Asia Pac J Oncol Nurs. 2017;4(3):224-32. https://doi. org/10.4103/apjon.apjon_22_17

PMid:28695169

23. Alkhateeb AA, Connor JR. The significance of ferritin in cancer: Anti-oxidation, inflammation and tumorigenesis. Biochim Biophys Acta. 2013;1836(2):245-54.

PMid:23891969

24. Nocka KH, Pelus LM. Cell cycle specific effects of deferoxamine on human and murine hematopoietic progenitor cells. Cancer Res. 1988;48(13):3571-5.

PMid:3378203

25. Kennedy TP, Rao NV, Noah W, Michael JR, Jafri MH Jr., Gurtner $\mathrm{GH}$, et al. Ibuprofen prevents oxidant lung injury and in vitro lipid peroxidation by chelating iron. $\mathrm{J}$ Clin Invest. 1990;86(5):1565-73. https://doi.org/10.1172/jci114876

PMid:2173723
26. Beguin Y. Prediction of response and other improvements on the limitations of recombinant human erythropoietin therapy in anemic cancer patients. Haematologica. 2002;87(11):1209-21.

PMid:12414352

27. Song A, Eo W, Kim S, Shim B, Lee S. Significance of serum ferritin as a prognostic factor in advanced hepatobiliary cancer patients treated with Korean medicine: A retrospective cohort study. BMC Complement Altern Med. 2018;18(1):176. https:// doi.org/10.1186/s12906-018-2240-7

PMid:29879960

28. Nemeth E, Rivera S, Gabayan V, Keller C, Taudorf S, Pedersen BK, et al. IL-6 mediates hypoferremia of inflammation by inducing the synthesis of the iron regulatory hormone hepcidin. J Clin Invest. 2004;113(9):1271-6. https://doi. org/10.1172/jci200420945

PMid:15124018 